\title{
Unusual type of benign X-linked muscular dystrophy
}

\author{
ALAN E. H. EMERY AND F. E. DREIFUSS \\ From the Department of Medical Genetics, Manchester University, Manchester, and the Division of Neurology, \\ University of Virginia School of Medicine, Charlottesville, Virginia, U.S.A.
}

Duchenne muscular dystrophy affects mainly young boys and is usually inherited as an X-linked recessive trait. The disease begins in infancy or early childhood and is characterized by weakness of the lower limbs and pelvic girdle musculature almost invariably associated with swollen calves ('pseudohypertrophy'). The weakness gradually progresses and ultimately the child becomes confined to a wheelchair by about the age of 10 and he dies at about 20 (Walton and Nattrass, 1954).

In recent years a more benign form of $\mathrm{X}$-linked muscular dystrophy has been recognized by Becker (Becker and Kiener, 1955; Becker, 1957; Becker, 1962). In this type of muscular dystrophy the onset is later than in the Duchenne type and the course of the disease is also slower so that affected persons may become chair ridden only after 25 to 30 years and the average life expectancy is only slightly decreased. However, apart from the late onset and benign course of the disease, the clinical picture is similar to that of Duchenne muscular dystrophy: weakness begins in the lower limbs and pelvic girdle musculature and only later affects the upper limbs and there is pseudo-hypertrophy of the calf muscles. Others have also described families in which the disease began later and the progression was slower than in the 'classical' Duchenne type of muscular dystrophy (Levison, 1951; Lamy and de Grouchy, 1954; Walton, 1955, 1956; Blyth and Pugh, 1959; Emery, 1964). Blyth and Pugh dismissed as unlikely the possibility of modifier genes being responsible for the different clinical manifestations in the two types of muscular dystrophy for the reason that they never found severe and mild cases of X-linked muscular dystrophy in the same family.

In 1961, Dreifuss and Hogan described a large family in Virginia in which eight male members were affected with a benign form of muscular dystrophy which was inherited as an X-linked recessive trait. This family has been studied again and evidence is presented which suggests that the muscular dystrophy in this family is distinct from that described by Becker and represents yet another type of $\mathrm{X}$-linked muscular dystrophy.
METHODS

All the males in this family, whether affected or unaffected, as well as the carrier females were carefully examined. Electrocardiography was carried out on all the males. Serum levels of creatine kinase were determined on fresh serum using the method of Tanzer and Gilvarg (1959) and the results are expressed in international units (number of $\mu \mathrm{M}$ of creatine transformed per minute per litre of serum at $p \mathrm{H} 9.0$ and $25^{\circ} \mathrm{C}$.). In this laboratory the upper limit of serum creatine kinase is 1.5 units in normal women (Emery and Pascasio, 1965) and about 1.8 units in healthy men. Colour vision testing was carried out using the Ishihara plates, the AO-HRR (American Optical-Hardy-Rand-Rittler) pseudo-isochromatic plates, and the Tokyo Medical College book. The Xg blood group was very kindly tested for by Dr. R. R. Race and Dr.气 Ruth Sanger, of the Lister Institute, London.

\section{CLINICAL FINDINGS}

The members of this large family are of English descent and live mainly in Buchanan County, Virgina. There are eight affected males in three generations and 16 unaffected carrier females (Fig. 1). The course of the disease in this family is remarkably uniform. In all cases the onset of muscle weakness was noted around the age of 4 or 5 , first affecting the lower extremities. Among the earliest manifestations of the disease in affected individuals is the development of flexion contractures of the elbows and shortening of the tendo Achillis. As a result of the shortening of the tendo Achillis there is an early tendency to walk on the toes and it has become a routine in this -family to have their heel cords lengthened some time during childhood. So far this has been done on all the affected males with the exception of $V_{2}$ (Fig. 1). The clinical findings in the individual members of the family are as follows.

$\mathrm{III}_{4}$ C.R. (proband) was aged 55 . He had a lordotic stance, was unable to rise from a chair without considerable difficulty, and had a marked waddling gait though he was still able to work full time as a school teacher. He was unable to abduct his arms more than $90^{\circ}$ and there was winging of both scapulae. There was wasting and weakness of the pelvic girdle musculature, including the quadriceps and hamstring muscles, and also some weakness of the pectoral girdle musculature, including the biceps and triceps muscles. The distal musculature both in the upper and lower extremities was apparently unaffected. All the deep tendon reflexes were absent. He 


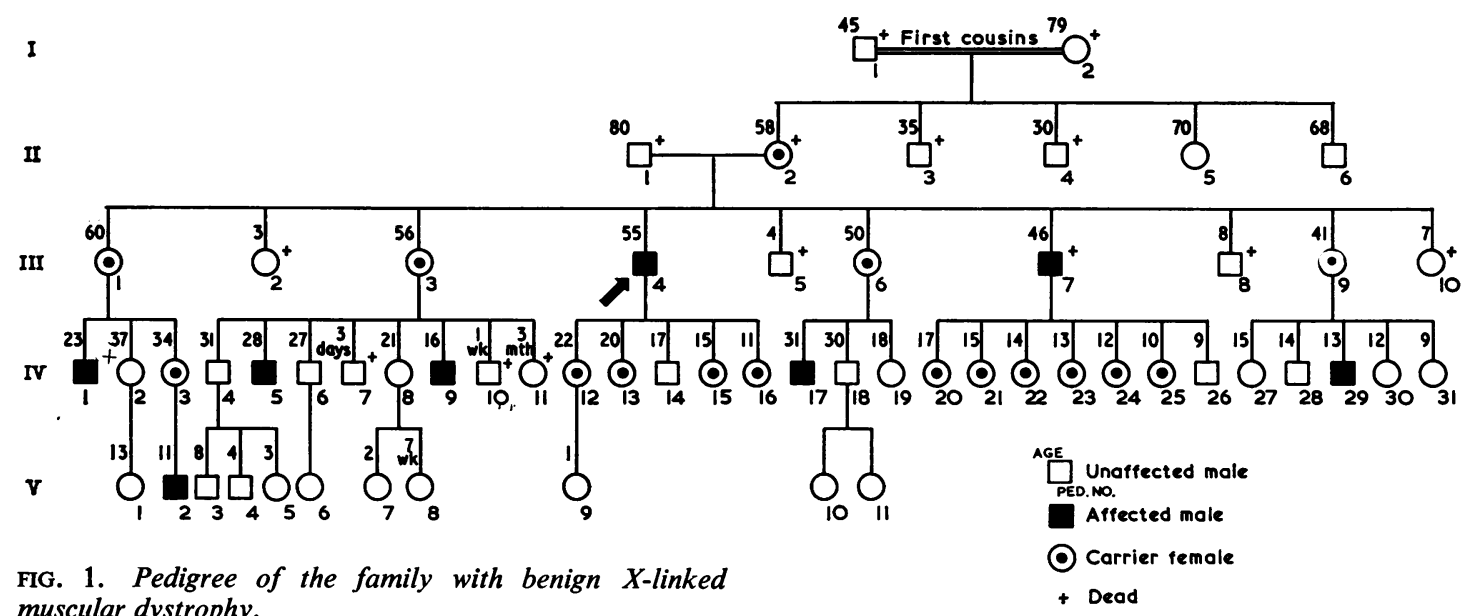
muscular dystrophy.

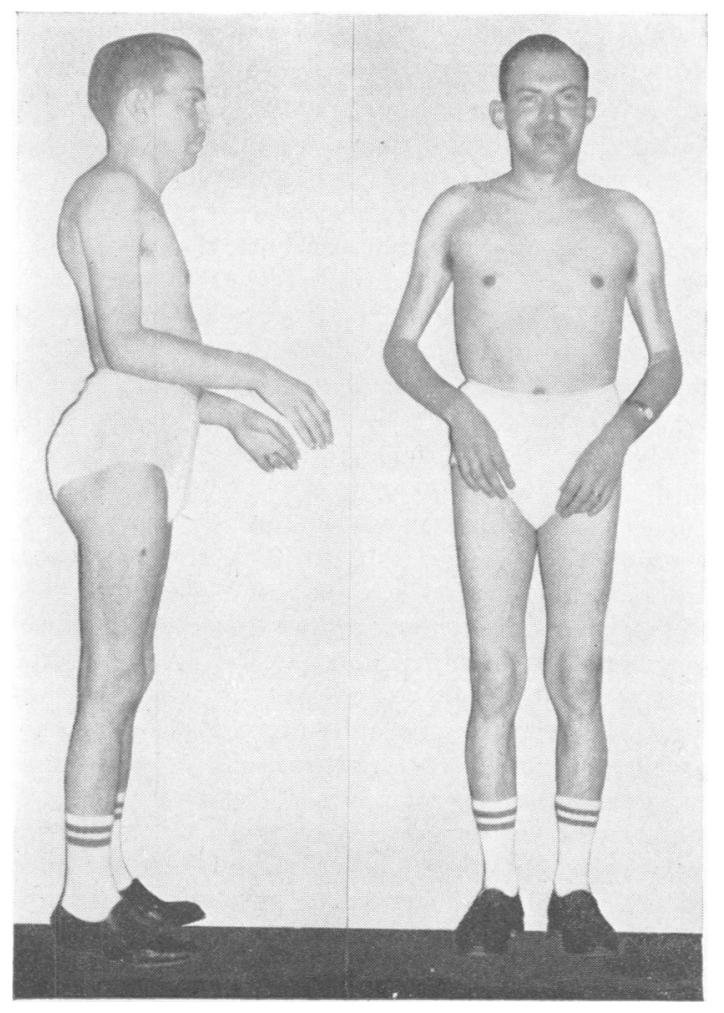

FIG. 2. Patient $I V_{5}$ age 28. Note the flexion contractures of the elbows. had some facial weakness with a mild myopathic facies. There were flexion contractures of both elbows and he was unable to extend his arms more than about $120^{\circ}$. He had a mild degree of pectus excavatum. Cardiac examination revealed a grade 3 mid-systolic murmur down the left sternal border. The heart sounds were normal. An electrocardiogram showed a nodal rhythm with occasional supraventricular ectopic beats.

In $\mathrm{III}_{7}$ G.R., the clinical findings were similar to those in his elder brother though he was less severely affected. He was actively engaged as a grocer until he had a fatal heart attack at the age of 46 .

IV 1 E.M. was not examined because he died some time ago at the age of 23 from 'cancer' (? seminoma of the testes). However, there is little doubt that he was also affected because he had muscle weakness which mainly affected the lower limbs and which progressed steadily up to the time of his death. From early childhood he had contractures of both elbows.

C $I_{5}$ K.Y., aged 28, had a lordotic stance and a waddling gait. The distribution of the muscle wasting and weakness was similar to that in the proband though he was much less severely affected. The deep tendon reflexes were absent. He had some facial weakness, the orbicularis oris muscle being mainly affected. There were flexion contractures of both elbows and he was unable to extend his arms more than about $100^{\circ}$. He had a mild degree of pectus excavatum. Cardiac examination revealed no abnormality apart from atrial fibrillation which was confirmed by electrocardiography. There was no history of rheumatic fever.

In IV ${ }_{9}$ H.Y., aged 16, there was no lordosis but he had a waddling gait with weakness of the hip flexors but normal power in the quadriceps and hamstring muscles. There was some weakness in the deltoids and winging of both scapulae. Apart from the knee jerks the remaining deep tendon reflexes were absent. There was no facial weakness. He had contractures of both elbows and could extend his arms no more than about $100^{\circ}$. He had a mild degree of pectus excavatum. Clinically and electrocardiographically there was no evidence of any cardiac abnormality. 
$\mathrm{IV}_{17}$ O.H., aged 31, has been unable to walk since the age of 24 probably due largely to his always having been extremely obese. There was marked weakness of the pelvic girdle musculature, including the quadriceps and hamstring muscles, and also weakness of the pectoral girdle musculature including the biceps and triceps muscles. All the deep tendon reflexes were absent. He had some facial weakness and contractures of both elbows so that he could not extend his arms more than about $100^{\circ}$. Cardiac examination revealed a soft mid-systolic murmur down the left sternal border maximal in the pulmonary area. His pulse rate was 42 and electrocardiography showed no evidence of atrial activity (? complete heart block or nodal rhythm).

$\mathrm{IV}_{29}$ S.C., aged 13, had a normal stance but he had a waddling gait. The distribution of the muscle weakness was similar to that in $\mathrm{IV}_{8}$ though he also had some minimal weakness of the orbicularis oris muscles. The deep tendon reflexes were depressed. He had contractures of both elbows and could not extend his arms more than $90^{\circ}$. He had a mild degree of pectus excavatum. Clinically and electrocardiographically there was no evidence of any cardiac abnormality. A biopsy from the left gastrocnemius muscle (A.F.I.P. No. 944528) showed foci of muscle fibres undergoing necrosis and phagocytosis. The intervening muscle showed some variation in fibre size and also an apparent increase in the number of sarcolemmal nuclei. There was little evidence of any replacement by fat or connective tissue.

$V_{2}$ S.E., aged 11, was the youngest affected member of of the family. He had a waddling gait and walked on his toes because of shortening of the heel cords. Except for slight weakness of the hip flexors and some winging of both scapulae the rest of the musculature appeared normal. The deep tendon reflexes were normal. There was no facial weakness. He had contractures of both elbows and could not extend his arms more than about $130^{\circ}$. Clinically and electrocardiographically there was no evidence of any cardiac abnormality.

All the female carriers were examined but none was found to have any muscle weakness.

The serum level of creatine kinase was raised in the affected males, gradually falling as the disease progressed (Table I). Of the 11 female carriers tested, only four had raised levels of serum creatine kinase. This contrasts with about $70 \%$ carriers of Duchenne type muscular dystrophy who have been found to have raised levels of

\section{TABLE I}

CLINICAL FINDINGS IN AFFECTED MEMBERS OF THE FAMILY

\begin{tabular}{|c|c|c|c|c|c|c|}
\hline \multirow[t]{2}{*}{ Patient } & \multirow[t]{2}{*}{ Age } & \multicolumn{3}{|c|}{ Muscle Weakness ${ }^{1}$} & \multirow{2}{*}{$\begin{array}{l}\text { Cardiac } \\
\text { Involve- } \\
\text { ment }\end{array}$} & \multirow{2}{*}{$\begin{array}{l}\text { Serum } \\
\text { Creatine } \\
\text { Kinase } \\
\text { (i.u.) }\end{array}$} \\
\hline & & $\begin{array}{l}\text { Lower } \\
\text { Extremi- } \\
\text { ties }\end{array}$ & $\begin{array}{l}\text { Upper } \\
\text { Extremi- } \\
\text { ties }\end{array}$ & Face & & \\
\hline $\begin{array}{l}\mathrm{III}_{4} \\
\mathrm{III}_{7} \\
\mathrm{IV}_{17} \\
\mathrm{IV}_{5} \\
\mathrm{IV}_{9} \\
\mathrm{IV}_{\mathbf{2 9}} \\
\mathrm{V}_{\mathbf{2}}\end{array}$ & $\begin{array}{l}55 \\
46 \\
31 \\
28 \\
16 \\
13 \\
11\end{array}$ & $\begin{array}{l}++++ \\
++++ \\
++++ \\
+++ \\
++ \\
++ \\
+\end{array}$ & $\begin{array}{l}++++ \\
++++ \\
++++ \\
++ \\
+ \\
+ \\
0\end{array}$ & $\begin{array}{l}\text { Moderate } \\
\text { Moderate } \\
\text { Moderate } \\
\text { Moderate } \\
\text { 0 } \\
\text { Minimal } \\
\text { 0 }\end{array}$ & $\begin{array}{l}\text { Yes } \\
\text { Yes } \\
\text { Yes } \\
\text { Yes } \\
\text { No } \\
\text { No } \\
\text { No }\end{array}$ & $\begin{array}{c}2 \cdot 2 \\
6 \cdot 2 \\
8 \cdot 4 \\
10 \cdot 6 \\
12 \cdot 3 \\
\end{array}$ \\
\hline
\end{tabular}

${ }^{1}$ Muscle weakness graded from normal $(0)$ to very weak $(++++)$. serum creatine kinase (Hughes, 1963; Pearce, Pennington, and Walton, 1964; Emery, 1965; Wiesmann, Moser, Richterich, and Rossi, 1965; Wilson, Evans, and Carter, 1965).

TABLE II

SERUM LEVELS OF CREATINE KINASE IN FEMALE CARRIERS

\begin{tabular}{llc} 
Carrier & Age & $\begin{array}{l}\text { Serum } \\
\text { Creatine Kinase (i.u.) }\end{array}$ \\
\hline C.H. III & 60 & 0.7 \\
V.Y. III & 56 & 1.9 \\
E.H. III & 50 & 2.4 \\
O.C. III, & 41 & 0.3 \\
J.R. IV & 15 & 0.6 \\
L.R. IV & 15 & 0.0 \\
B.R. IV & 14 & 1.7 \\
L.R. IV & 13 & 1.5 \\
P.R. IV & 12 & 1.7 \\
S.R. IV & 11 & 0.7 \\
V.R. IV & 10 & 0.8
\end{tabular}

${ }^{1}$ Normal less than 1.5 international units

None of the male members of this family is colour blind and all are $\mathrm{Xg}(\mathrm{a}+)$. Therefore the family is uninformative as regards linkage between the genes for this type of muscular dystrophy and these $\mathrm{X}$-linked marker traits.

\section{DISCUSSION}

The type of muscular dystrophy in this famil appears to be inherited as an X-linked recessive trait because only males are affected, it is trans mitted by unaffected females (carriers), and in the two cases where affected males have had sons the latter have been perfectly normal $\left(\mathrm{IV}_{14}\right.$ and $\left.I \mathrm{IV}_{26}\right)$ However, it has not been possible to demonstrate linkage between the genes for this type of muscular dystrophy and the $\mathrm{X}$-linked marker traits because all the male members of the family (both affected and unaffected) have normal colour vision and all are $\mathrm{Xg}(\mathrm{a}+)$.

The clinical features and course of the disease in this family are remarkably uniform. In all cases the onset was around the age of 4 or 5 with weakness of the pelvic girdle musculature and only later was the pectoral girdle musculature affected. Characteristic of the disease is the very slow progress; the proband, for example, is still ambulatory at the age of 55 and his brother was actively engaged as a grocer until he had a fatal heart attack at the age of 46. All the affected members have the following features in common: contractures of both elbows and shortening of the tendo Achillis dating from early childhood, mild pectus excavatum, and absence of pseudo-hypertrophic calves. Several have moderate weakness of the orbicularis oris and lower facial muscles. None are mentally retarded and in fact two are school teachers $\left(\mathrm{III}_{4}\right.$ and $\left.\mathrm{IV}_{5}\right)$. Among the older 
affected males abnormal cardiac rhythms, nonspecific murmurs and sudden death have been observed and such manifestations have been interpreted as evidence of myocardial involvement in patients with other types of muscular dystrophy (Zatuchni, Aegerter, Molthan, and Shuman, 1951; Rubin and Buchberg, 1952; Weisenfeld and Messinger, 1952; Lisan, Imbriglia, and Likoff, 1959; Gilroy, Cahalan, Berman, and Newman, 1963; Storstein, 1964). It seems reasonable to assume therefore that the clinical manifestations of cardiac disease in four of the patients are not fortuitous associations but represent evidence of cardiac involvement as part of the dystrophic process.

The muscular dystrophy in this family resembles that described by Becker (1962) in its mode of inheritance, its benign course, and the distribution of the muscle weakness. However, there are several features of the disease in this family which would seem to distinguish it from the Becker type of muscular dystrophy: flexion contractures of the elbows and shortening of the heel cords dating from early childhood, the distal muscles are not affected even late in the disease, and there is no pseudohypertrophy of the calf muscles. Myocardial involvement in the older affected males in this family may represent another difference from the Becker type of muscular dystrophy but this is not clear because there appears to have been no reported study of the cardiological status of patients with Becker type muscular dystrophy. Myocardial involvement in Duchenne muscular dystrophy is well recognized (Skyring and McKusick, 1961; Lowenstein, Arbeit, and Rubin, 1962; Gilroy, et al., 1963; Welsh, Lynn, and Haase, 1963). None of the affected males in this family appears to be mentally retarded whereas half of Becker's cases were feeble minded. However it is difficult to assess whether this represents a real difference between the two types of muscular dystrophy. Mental retardation has been shown to occur in a significant proportion of children with Duchenne muscular dystrophy (Allen and Rodgin, 1960; Worden and Vignos, 1962; Dubowitz, 1965).

Recently Mabry, Roeckel, Munich, and Robertson (1965) described a large family with a benign form of X-linked muscular dystrophy which the authors consider differs from the Becker type of muscular dystrophy in its age of onset and the greater degree of disability which it produces. X-linked muscular dystrophy may therefore exist in at least four distinct types: Duchenne type, Becker type, and the rare types described by Mabry et al., and in this report. Unfortunately little is known of the essential biochemical nature of the muscular dystrophies and therefore the subdivision of the benign $\mathrm{X}$-linked variety must remain somewhat conjectural. However,
TABLE III

DIFFERENTIATING FEATURES BETWEEN THE FOUR TYPES OF X-LINKED MUSCULAR DYSTROPHY

\begin{tabular}{|c|c|c|c|c|c|}
\hline Type & $\begin{array}{l}\text { Usual Age } \\
\text { of Onset } \\
\text { of } \\
\text { Weakness }\end{array}$ & Course & $\begin{array}{l}\text { Pseudo- } \\
\text { hyper- } \\
\text { trophy' }\end{array}$ & $\begin{array}{l}\text { Myo- } \\
\text { cardial } \\
\text { Involve- } \\
\text { ment }\end{array}$ & Contractures \\
\hline Duchenne & $<5$ & Severe & + & + & $\begin{array}{l}+ \\
\text { (late mani- } \\
\text { festation) }\end{array}$ \\
\hline Becker & $5-25$ & Benign & + & $?$ & - \\
\hline $\begin{array}{l}\text { Mabry } \\
\text { Present }\end{array}$ & $11-13$ & Benign & + & + & - \\
\hline family & $4-5$ & Benign & - & + & $\begin{array}{l}+ \\
\text { (early mani- } \\
\text { festation) }\end{array}$ \\
\hline
\end{tabular}

in order to understand the pathogenesis of these diseases the clinical grouping of apparently dissimilar types would seem to be an important first step.

\section{SUMMARY}

A family is described with a benign form of X-linked muscular dystrophy. The course of the disease is remarkably uniform. In all cases the onset of muscle weakness was noted around the age of 4 or 5 , first affecting the pelvic girdle musculature and later affecting the pectoral girdle musculature, the distal musculature being spared. Other features of the disease include flexion contractures of the elbows and shortening of the tendo Achillis dating from early childhood, mild facial weakness, absence of pseudo-hypertrophy, myocardial involvement in some cases, and normal intelligence. Reasons are presented for considering this as possibly a distinct type of benign X-linked muscular dystrophy.

Our grateful thanks are due to Dr. Ellis Epstein and Dr. S. N. Schimke for their invaluable help at various stages of this investigation, and to the Armed Forces Institute of Pathology (Director, Colonel J. M. Blumberg) for permission to study their histological preparations of a muscle biopsy on patient S.C. $\left(\mathrm{IV}_{29}\right)$. We are also grateful to Professor P. E. Becker and Professor V. A. McKusick for advice and helpful suggestions and to the Department of Medical Illustration at Manchester Royal Infirmary for their assistance with the illustrations.

\section{REFERENCES}

Allen, J. E., and Rodgin, D. W. (1960). Mental retardation in association with progressive muscular dystrophy. Amer. J. Dis. Child., 100, 208-211.

Becker, P. E. (1957). Neue Ergebnisse der Genetik der Muskeldystrophien. Acta genet. (Basel), 7, 303-310.

(1962). Two new families of benign sex-linked recessive muscular dystrophy. Rev. canad. Biol., 21, 551-566.

- - and Kiener, F. (1955). Eine neue X-chromosomale Muskeldystrophie. Arch. Psychiat. Nervenkrank., 193, 427-448.

Blyth, H., and Pugh, R. J. (1959). Muscular dystrophy in childhood. The genetic aspect. A field study in the Leeds region of clinical types and their inheritance. Ann. hum. Genet., 23, 127-163. 
Dreifuss, F. E., and Hogan, G. R. (1961). Survival in X-chromosomal muscular dystrophy. Neurology (Minneap.), 11, 734-737.

Dubowitz, V. (1965). Intellectual impairment in muscular dystrophy. Arch. Dis. Childh., 40, 296-301.

Emery, A. E. H. (1964). Hereditary myopathies. Clin. Orthop., 33, 164-173.

- (1965). Investigations of female carriers of the Duchenne type muscular dystrophy. In Research in Muscular Dystrophy, pp. 90-97. Pitman Medi_al Publishing Co., London.

—, and Pascasio, F. M. (1965). The effects of pregnancy on the concentration of creatine kinase in serum, skeletal muscle, and myometrium. Amer. J. Obstet. Gynec., 91, 18-22.

Gilroy, J., Cahalan, J. L., Berman, R., and Newman, M. (1963). Cardiac and pulmonary complications in Duchenne's progressive muscular dystrophy. Circulation, 27, 484-493.

Hughes, B. P. (1963). Serum enzyme studies with special reference to the Duchenne type dystrophy. In Research in Muscular Dystrophy, Proc. 2nd Symposium of Muscular Dystrophy Group, pp. 167-179. Pitman Medical Publishing Co., L ond on.

Lamy, M., and de Grouchy, J. (1954). L'hérédite de la myopathie (formes basses). J. Génét. hum., 3, 219-261.

Levison, H. (1951). Dystrophia musculorum progressiva; clinical and diagnostic criteria; inheritance. Acta psychiat. scand., suppl. 76.

Lisan, P., Imbriglia, J., and Likoff, W. (1959). Myocardial disease associated with progressive muscular dystrophy (a report of 2 cases). Amer. Heart J., 57, 913-920.

Lowenstein, A. S., Arbeit, S. R., and Rubin, I. L. (1962). Cardiac involvement in progressive muscular dystrophy. An electrocardiographic and ballistocardiographic study. Amer. J. Cardiol., 9, 528-533.

Mabry, C. C., Roeckel, I. E., Munich, R. L., and Robertson, D. (1965). $\mathrm{X}$-linked pseudohypertrophic muscular dystrophy with a late onset and slow progression. New Engl. J. Med., 273, 1062-1070.

Pearce, J. M. S., Pennington, R. J., and Walton J. N. (1964). Serum enzyme studies in muscle disease. Part 1 . Variations in serum creatine kinase activity in normal individuals. J. Neurol. Neurosurg. Psychiat., 27, 1-4

Rubin, I. L., and Buchberg, A. S. (1952). The heart in progressive muscular dystrophy. Amer. Heart. J., 43, 161-169.

Skyring, A., and McKusick, V. A. (1961). Clinical, genetic and electrocardiographic studies in childhood muscular dystrophy. Amer. J. med. Sci., 242, 534-547.

Storstein, O. (1964). The heart in progressive muscular dystrophy. Exp. Med. Surg., 22, 13-23.

Tanzer, M. L., and Gilvarg, C. (1959). Creatine and creatine kinase measurement. J. biol. Chem., 234, 3201-3204.

Walton, J. N. (1955). On the inheritance of muscular dystrophy. Ann. hum. Genet., 20, 1-38.

(1956). The inheritance of muscular dystrophy: further observations. Ibid., 21, 40-58.

$\longrightarrow$, and Nattrass, F. J. (1954). On the classification, natural history and treatment of the myopathies. Brain, 77, 169-231.

Weisenfeld, S., and Messinger, W. J. (1952). Cardiac involvement in progressive muscular dystrophy. Amer. Heart J., 43, 170-187.

Welsh, J. D., Lynn, T. N., and Haase, G. R. (1963). Cardiac findings in 73 patients with muscular dystrophy. Arch. intern. Med., 112, 199-206.

Wiesmann, U., Moser, H., Richterich, R., and Rossi, E. (1965). है Progressive Muskeldystrophie. VII. Die Erfassung von Heterozygoten der Duchenne-Muskeldystrophie durch Messung der Serum-Kreatin-Kinase unter lokalisierter Arbeitsbelastung in Anoxie. Klin. Wschr., 43, 1015-1022.

Wilson, K. M., Evans, K. A., and Carter, C. O. (1965). Creatine kinase levels in women who carry genes for three types of muscular dystrophy. Brit. med. J., 1, 750-753.

Worden, D. K., and Vignos, P. J. Jr. (1962). Intellectual function in childhood progressive muscular dystrophy. Pediatrics, 29, 968-977.

Zatuchni, J., Aegerter, E. E., Molthan, L., and Shuman, C. R. (1951) it The heart in progressive muscular dystrophy. Circulation, 3- $\omega$ 846-853. 